\title{
The Roles of Hypoxia-Inducible Factors and Non-Coding RNAs in Gastrointestinal Cancer
}

\author{
Hyun-Soo Cho ${ }^{1,+}+\mathbb{D}$, Tae-Su Han ${ }^{1,+}$, Keun Hur ${ }^{2, *} \mathbb{D}$ and Hyun Seung Ban ${ }^{1, * \mathbb{C}}$ \\ 1 Korea Research Institute of Bioscience and Biotechnology, Daejeon 34141, Korea; chohs@kribb.re.kr (H.-S.C.); \\ tshan@kribb.re.kr (T.H.) \\ 2 Department of Biochemistry and Cell Biology, School of Medicine, Kyungpook National University, \\ Daegu 41944, Korea \\ * Correspondence: KeunHur@knu.ac.kr (K.H.); banhs@kribb.re.kr (H.S.B.); \\ Tel.: +82-53-420-4821 (K.H.); +82-42-879-8176 (H.S.B.) \\ + These authors contributed equally to this work.
}

Received: 10 November 2019; Accepted: 2 December 2019; Published: 4 December 2019

check for updates

\begin{abstract}
Hypoxia-inducible factors (HIFs) are transcription factors that play central roles in cellular responses against hypoxia. In most cancers, HIFs are closely associated with tumorigenesis by regulating cell survival, angiogenesis, metastasis, and adaptation to the hypoxic tumor microenvironment. Recently, non-coding RNAs (ncRNAs) have been reported to play critical roles in the hypoxic response in various cancers. Here, we review the roles of hypoxia-response ncRNAs in gastrointestinal cancer, with a particular focus on microRNAs and long ncRNAs, and discuss the functional relationships and regulatory mechanisms between HIFs and ncRNAs.
\end{abstract}

Keywords: hypoxia; non-coding RNA; microRNA; hypoxia-inducible factor; gastrointestinal cancer

\section{Introduction}

Gastrointestinal (GI) cancer is the most common type of cancer and second leading cause of cancer-related death [1]. GI cancer is particularly difficult to treat since it is usually found in an advanced stage. The abnormal growth of cancer cells induces hypoxic conditions in most solid tumors as well as GI cancers [2]. Hypoxia-inducible factors (HIFs) are heterodimeric transcription factors consisting of two oxygen response subunits (HIF- $1 \alpha$ and $-2 \alpha$ ) and a constitutively expressed subunit (aryl hydrocarbon receptor nuclear translocator; ARNT, also known as HIF-1 $\beta$ ) [3,4]. In the presence of oxygen, the posttranslational proline hydroxylation of HIF- $1 \alpha$ by prolyl hydroxylase (PHD) leads to E3 ubiquitin ligase von Hippel-Lindau (VHL)-mediated ubiquitination, resulting in HIF-1 $\alpha$ degradation via the ubiquitin-proteasome system [5]. Under hypoxic conditions, HIF- $1 \alpha$ translocates into the nucleus where it dimerizes with HIF-1 $\beta$ and binds to hypoxia-response elements (HREs; $5^{\prime}$-RCGTG-3', where $\mathrm{R}$ is $\mathrm{A}$ or $\mathrm{G}$ ) in the promoter regions of target genes, including erythropoietin (EPO), vascular endothelial growth factor (VEGF), glucose transporters, and glycolytic enzymes [6-8]. HIFs are therefore pivotal regulators of the tumor microenvironment and are involved in cancer cell growth, migration, angiogenesis, and resistance to cancer therapy $[9,10]$. Indeed, enhanced HIF- $1 \alpha$ expression has been detected in various cancers, including lung, breast, colon, and liver cancers, and is significantly correlated with low patient survival rates $[9,11]$. Thus, HIFs are an attractive therapeutic target for treating cancer.

MicroRNAs (miRNAs) are small non-coding RNAs (ncRNAs) whose first transcripts (pri-miRNAs) are typically produced by RNA polymerase II [12]. Pri-miRNAs are then cleaved by a microprocessor complex (DGCR8 and Drohsa) into stem-loop structures of $\sim 70-110$ nucleotides (nt), known as pre-miRNAs. These pre-miRNAs are translocated from the nucleus to the cytoplasm by the 
Ran/GTP/Exportin5 complex, where they are then processed into mature duplex miRNAs of 21-25 nt by the RNase III enzyme, Dicer. After the duplex has been unwound, mature miRNAs can regulate their target genes alongside the RNA-induced silencing complex (RISC) [13,14], playing important roles in post-transcriptional regulation. The first miRNA to be identified was lin-4 in Caenorhabditis elegans (C. elegans) [15], which affects development by regulating the lin-14 protein. After seven years, another miRNA was reported in C. elegans, let-7, which negatively regulates lin- 41 via sequence-specific interactions with its $3^{\prime}$-untranslated region (3'-UTR) [16]. The development of microarray and RNA sequencing techniques have led to the discovery of numerous novel and conserved miRNAs in vertebrates. We currently know of over 1800 annotated human precursor miRNAs that are processed into over 2500 mature miRNA sequences; however, the functions of many of these miRNAs in various aspects of cancer remain unknown.

Long non-coding RNAs (lncRNAs), which are generally over $200 \mathrm{nt}$ in length (typically 1000-10000 $\mathrm{nt}$ ) and have no protein-coding potential, are now known to be important regulators of cellular processes such as development and metabolism. LncRNAs are transcribed by RNA polymerase II and undergo multiple exon splicing $[17,18]$; however, their dysregulation is widely associated with diseases such as cancer [19], with abnormal lncRNA transcript expression linked to the progression and metastasis of cancer and patient survival. LncRNAs can also act as tumor suppressors (e.g. BGL3, GAS5, PTENP1, and MEG3) or oncogenes (e.g. HOTAIR, MALAT1, PCAT1/5/18, PVT1, UCA1, and XIST) in cancer [20-22], and can act as sponges to regulate miRNAs by competitively binding with their target genes, thereby increasing miRNA target gene expression. However, despite the close link between IncRNAs and cancer progression, their functions in cancer are not fully understood.

Here, we review the close relationship between HIFs and ncRNAs, the regulation of their expression, molecular function, and cellular responses to hypoxia in GI cancers. Furthermore, we discuss the potential therapeutic applications of ncRNAs to treat hypoxic cancers.

\section{HIF-Related ncRNAs in Gastric Cancer (GC)}

\section{1. ncRNAs Regulate HIF Expression in GC}

Many studies have demonstrated that altered miRNA expression is involved in hypoxia in cancer by targeting HIFs. For instance, miR-18a expression is downregulated under hypoxic conditions in GC cell lines [23], with miR-18a overexpression increasing the number of apoptotic cells and decreasing cell invasion by directly targeting HIF- $1 \alpha$. In addition, miR-186 has been reported to have anti-proliferative roles in some cancers; in GC, miR-186 suppresses cell proliferation by negatively regulating HIF-1 $\alpha$ [24] and consequently affects downstream HIF- $1 \alpha$ target genes, including PD-L1, hexokinase 2, and PFKP. Therefore, miR-186 functions as a tumor suppressor in GC. HIF- $1 \alpha$ expression is also negatively regulated by miR-143-5p, but is positively correlated with the expression of the lncRNA ZEB2-AS1 in GC [25]. Bioinformatic analysis has revealed that ZEB2-AS1 can be regulated by miR-143-5p; therefore, ZEB2-AS1-mediated GC progression may involve the miR-143-5p/HIF-1 $\alpha$ axis.

It has also been shown that overexpression of the lncRNA plasmacytoma variant translocation1 (PVT1) promotes multidrug resistance in GC cells [26], with high PVT1 expression observed in cisplatin-resistant GC patients. PVT1 knockdown has been found to reduce cisplatin resistance and increase apoptosis in GC cells, while PVT1 overexpression has anti-apoptotic effects and increases the expression of the drug resistance-related genes MDR1, MRP, mTOR, and HIF- $1 \alpha$. Other studies have shown that PVT1 can regulate miR-186 [27] and that PVT1 expression is upregulated in GC tissues and associated with lymph node metastasis. Furthermore, a functional study found that PVT1 overexpression promotes cell proliferation and invasion, with PVT1 upregulation increasing HIF- $1 \alpha$ levels by sponging miR-186 in GC.

Crocin is a key bioactive compound with well known anti-inflammatory, anti-oxidant, and anti-cancer effects. In GC, crocin has been found to suppress the migration, invasion, and epithelial-to-mesenchymal transition (EMT) of GC cells by modulating miR-320/KLF5/HIF- $1 \alpha$ 
signaling [28]. Analysis of clinical GC samples revealed that both KLF5 and HIF-1 $\alpha$ expression are upregulated in GC tissues and that KLF5 expression is positively correlated with HIF-1 $\alpha$ expression. Moreover, crocin treatment decreases KLF5 and HIF- $1 \alpha$ expression but increases miR-320 expression, with target gene validation revealing that miR-320 negatively regulates KLF5 expression in GC. Although miR-320 regulates HIF- $1 \alpha$ indirectly, its signaling is important for understanding the regulatory mechanism of HIF- $1 \alpha$.

\subsection{HIFs Regulate ncRNA Expression in GC}

miR-210 is a representative hypoxia-specific miRNA that has been identified in various tumor types, including GC, with hypoxic conditions able to induce miR-210 expression in SGC-7901 GC cells in a time dependent manner [29]. By acting as a transcription factor, HIF- $1 \alpha$ can transcriptionally activate and upregulate miR-210 expression, which can affect chemoresistance, invasion, and metastasis by inhibiting its target gene, HOXA9, and increasing the expression of the EMT-related genes vimentin and $\mathrm{N}$-cadherin. Moreover, $\mathrm{Chen}$ et al. found that miR-210 expression is regulated by epigenetic factors, with oxLDL decreasing DNA methylation at the miR-210 promoter site where HIF- $1 \alpha$ binds [30]. This hypomethylation of the miR-210 promoter by oxLDL increases the likelihood of HIF- $1 \alpha$ binding to the miR-210 promoter site in GC to upregulate miR-210 expression. Recently, Zhang et al. suggested that phosphatase of regenerating liver-3 (PRL-3) regulates GC cell invasiveness by acting as an upstream regulator of HIF- $1 \alpha$; PRL-3 activates NF-kB signaling and promotes HIF- $1 \alpha$ expression, consequently inducing miR-210 expression [31]. These findings suggest that the PRL-3/NF-kB/miR-210 axis promotes cell migration and invasion, and is related to poor prognosis in patients with GC.

It has been reported that angiogenic miR-382 is also upregulated by hypoxia. Seok et al. identified miR-382 using a miRNA microarray technique with MKN1 human GC cells, finding that miR-382 is upregulated by HIF- $1 \alpha$ under hypoxic conditions [32]. Moreover, miR-382 upregulation decreases the expression of its target genes, phosphatase, and tensin homolog (PTEN) and activates the AKT/mTOR signaling pathway, indicating that HIF- $1 \alpha$-induced miR-382 promotes angiogenesis and acts as an oncogene by targeting PTEN in GC. The same research group also analyzed the clinical significance and prognostic role of hypoxia-induced miR-382 in GC [33], finding that miR-382 is significantly upregulated in GC tissues and could therefore be a prognostic marker for advanced GC. These reports suggest that miR-382 plays important roles in malignant GC development. MiR-107 has also been studied as a hypoxia-specific miRNA in GC. Analysis of GC patient serum and tissue samples found that miR-107 expression is higher in both sample types and positively correlated with HIF-1 $\alpha$ expression [34], suggesting that miR-107 could be used as a diagnostic biomarker for patients with GC.

HIF- $1 \alpha$-mediated miRNA expression has also been found to affect drug resistance. HIF-1 $\alpha$ knockdown decreases miR-27a levels and inhibits the proliferation of GC cells, with dual luciferase reporter assays and ChIP analysis revealing that HIF- $1 \alpha$ can directly bind to the miR-27a promoter and enhance its transcriptional activity [35]. Moreover, suppressing HIF-1 $\alpha$ or miR-27a decreased MDR1/P-gp, Bcl-2, and LRP expression, suggesting that HIF-1 $\alpha$ is closely associated with multi-drug resistance in GC via miR-27a expression. miR-421 is also a drug resistance-related miRNA induced by HIF-1 $\alpha$ in GC [36], whose upregulated expression in GC tissues is associated with decreased patient survival. Overexpressing miR-421 in GC cells was found to promote metastasis and induce cisplatin resistance in vivo and in vitro, exerting its oncogenic functions by targeting the E-cadherin and caspase-3 genes.

Other miRNAs, such as miR-214 and miR-224, have also been identified as hypoxia-inducible miRNAs in GC [37,38]. Both miR-214 and miR-224 are upregulated in GC tissue samples, with their overexpression promoting the growth and migration of GC cells and their inhibition having the opposite effects under hypoxic conditions. Furthermore, target gene validation revealed that miR-224 directly regulates RASFF8, which reduces the transcriptional activity of NF-kB and p65 translocation, whereas miR-214 negatively regulates the adenosine A2A receptor (A2AR) and PR/SET domain 16 (PRDM16) in GC. 
It has been reported that the lncRNA, urothelial cancer associated 1 (UCA1) is upregulated in hypoxia-resistant GC cell lines and promotes their migration [39]. Bioinformatics analysis and in vitro assays revealed that miR-7-5p can bind to UCA1-specific sites to regulate EGFR by reducing the binding efficiency of miR-7-5p for the EGFR transcripts. Therefore, hypoxia-induced UCA1 promotes cell migration by increasing EGFR expression in GC. Hypoxia can also induce the lncRNA BC005927 in GC cells, which is involved in hypoxia-induced metastasis [40], frequently upregulated in GC samples, and associated with poor prognosis, with high BC005927 expression decreasing the overall survival of patients with GC. ChIP and luciferase reporter assays have shown that BC005927 is directly regulated by HIF- $1 \alpha$ and upregulated by the metastasis-related gene, EPHB4. Therefore, hypoxic conditions induce HIF-1 $\alpha$, BC005927, and EPHB4 expression in GC cells, resulting in increased metastasis. Another hypoxia-induced lncRNA, prostate cancer gene expression marker 1 (PCGEM1), has also been identified in GC [41]. PCGEM1 is also overexpressed in GC tissues and its expression is upregulated by hypoxia in GC cells, with PCGEM1 knockdown significantly repressing GC cell invasion and metastasis. Additionally, PCGEM1 positively regulates the expression of SNAI1, a key transcription factor for EMT. Gastric adenocarcinoma associated, positive CD44 regulator, long intergenic non-coding RNA (GAPLINC) is also upregulated in GC tissues and associated with poor prognosis; moreover, it is directly activated by HIF- $1 \alpha$ at the transcriptional level in GC, with GAPLINC knockdown suppressing hypoxia-induced tumor growth in vivo [42].

Microarray techniques have been used to identify lncRNAs that are differentially expressed under hypoxic conditions, including AK123072 and AK058003 which are upregulated by hypoxia [43,44]. Both are frequently upregulated in GC samples and promote cell migration and invasion, with AK123072 positively correlated with EGFR expression and AK058003 positively correlated with $\gamma$-synuclein (SNCG) expression in GC samples. Thus, these techniques may help develop therapeutic agents against GC. HIF-related ncRNAs in GC are summarized in Table 1. 
Table 1. Hypoxia-inducible factor (HIF)-related non-coding RNAs (ncRNAs) in gastric cancer (GC).

\begin{tabular}{|c|c|c|c|}
\hline Non-coding RNAs & Functions & Targets & Ref. \\
\hline $\operatorname{miR}-18 \mathrm{a}$ & $\begin{array}{l}\text { Promotes apoptosis and reduces cell invasion by } \\
\text { regulating HIF- } 1 \alpha\end{array}$ & $\mathrm{HIF}-1 \alpha$ & [23] \\
\hline $\operatorname{miR}-186$ & $\begin{array}{l}\text { Directly regulates HIF- } 1 \alpha \text { and inhibits cell } \\
\text { proliferation }\end{array}$ & $\mathrm{HIF}-1 \alpha$ & [24] \\
\hline miR-143 & Directly regulates HIF- $1 \alpha$ & HIF-1 $\alpha$, ZEB2-AS1 & [25] \\
\hline PVT1 & $\begin{array}{c}\text { Enhances multidrug resistance and is associated } \\
\text { with lymph node metastasis }\end{array}$ & $\begin{array}{l}\text { HIF-1 } \alpha, \text { MDR1, MRP, } \\
\text { mTOR }\end{array}$ & {$[26,27]$} \\
\hline $\operatorname{miR}-320$ & $\begin{array}{c}\text { Upregulated by crocin and regulates HIF- } 1 \alpha \text { by } \\
\text { inhibiting KLF5 }\end{array}$ & KLF5 & [28] \\
\hline $\operatorname{miR}-210$ & $\begin{array}{c}\text { Regulates chemoresistance, invasion, and } \\
\text { metastasis } \\
\left.\text { (HRE region in miR-210 promoter }{ }^{1}\right)\end{array}$ & HOXA9 & {$[29,30]$} \\
\hline miR-382 & $\begin{array}{l}\text { Enhances angiogenesis } \\
\left(\text { HRE region in miR-382 promoter }{ }^{1}\right)\end{array}$ & PTEN & {$[32,33]$} \\
\hline miR-107 & Upregulated in GC serum and tissue samples & & [34] \\
\hline $\operatorname{miR}-27 a$ & $\begin{array}{l}\text { Regulates cell proliferation and drug resistance } \\
\left(\text { HRE region in miR-27a promoter }{ }^{1} \text { ) }\right.\end{array}$ & & [35] \\
\hline $\operatorname{miR}-421$ & $\begin{array}{l}\text { Upregulated in GC tissues. Regulates metastasis } \\
\text { and cisplatin resistance } \\
\left(\text { HRE region in miR-421 promoter }{ }^{1}\right)\end{array}$ & CDH1, CASP3 & [36] \\
\hline miR-214 & $\begin{array}{l}\text { Upregulated in GC tissues. Enhances cell } \\
\text { proliferation and migration }\end{array}$ & A2AR, PRDM16 & [37] \\
\hline $\operatorname{miR}-224$ & $\begin{array}{l}\text { Regulates cell proliferation and migration } \\
\text { (HRE region in miR-224 promoter }{ }^{1} \text { ) }\end{array}$ & RASFF8 & [38] \\
\hline UCA1 & Promotes hypoxia-induced cell migration & $\operatorname{miR}-7-5 p$ & [39] \\
\hline ВC005927 & $\begin{array}{l}\text { Upregulated in GC and is associated with poor } \\
\text { prognosis. Promotes metastasis } \\
\left.\text { (HRE region in } \text { IncRNA promoter }^{1}\right)\end{array}$ & EPHB4 & [40] \\
\hline PCGEM1 & $\begin{array}{l}\text { Regulates GC cell invasion, metastasis, and EMT } \\
\text { Upregulated in GC and is associated with poor }\end{array}$ & SNAI1 & [41] \\
\hline GAPLINC & $\begin{array}{l}\text { prognosis } \\
\left(\text { HRE region in lncRNA promoter }{ }^{1}\right)\end{array}$ & & [42] \\
\hline AK123072 & $\begin{array}{l}\text { Upregulated in GC tissues. Regulates cell } \\
\text { migration and invasion }\end{array}$ & & [43] \\
\hline AK053003 & Regulates GC cell migration and invasion & SNCG & [44] \\
\hline
\end{tabular}

\section{HIF-Related ncRNAs in Colorectal Cancer (CRC)}

\section{1. ncRNAs Regulate HIF Expression in CRC}

Circulating upregulated miR-210 and miR-21 and downregulated miR-126 expression have shown potential as diagnostic biomarkers for CRC as they are involved in the HIF- $1 \alpha /$ VEGF signaling pathways for colon cancer initiation [45]. During EMT and mesenchymal-to-epithelial transition (MET), HIF-1 $\alpha$ up-regulates the expression of Achaete scute-like2 (Ascl2), a transcriptional regulator of miR-200b, by binding to the HRE site at the Ascl2 promoter. Under hypoxic conditions, Ascl2 overexpression by HIF- $1 \alpha$ induces EMT by repressing miR-200b; however, since HIF- $1 \alpha$ is a direct target of miR-200b, the HIF-1 $\alpha$-Ascl2-miR-200b axis allows regulatory feedback for CRC EMT-MET plasticity [46]. In addition, miR-199a downregulation has been associated with CRC metastasis and incidence, while miR-199a overexpression suppresses the proliferation, migration, and invasion of CRC cell lines by reducing HIF-1 $\alpha$ /VEGF expression [47].

During CRC development, factor inhibiting HIF-1 $\alpha$ (FIH-1) represses the HIF- $1 \alpha$ pathway [48], suggesting that the association between FIH and HIF affects tumor development. FIH-1 is a direct target of miR-31, which is overexpressed in CRC and associated with CRC development by reducing FIH expression. Treatment with miR-31 inhibitors has been shown to reduce cell growth, migration, and invasion by inducing FIH expression and reducing HIF- $1 \alpha$ pathway signaling. In addition, in 
clinical CRC cohorts, miR-31 and FIH expression are negatively correlated [49], with miR-22 directly regulating HIF-1 $\alpha$ expression by binding the $3^{\prime}$ UTR of HIF- $1 \alpha$. Furthermore, overexpressing miR-22 in HCT116 cell lines reduces VEGF expression and represses cell growth and invasion by downregulating HIF-1 $\alpha$ expression [50].

In colon cancer, p53 transcriptionally regulates miR-107 to regulate hypoxic signaling, while miR-107 directly regulates HIF-1 $\beta$ expression. Overexpressing miR-107 negates the effects of hypoxia by reducing HIF-1 $\beta$ expression, whereas miR-107 knockdown induces hypoxic signaling by increasing HIF-1 $\beta$ expression. In vivo phenotype analysis found that miR-107 overexpression reduces tumor growth, VEGF expression, and angiogenesis in mice. Furthermore, a CRC cohort study found that miR-107 expression is inversely associated with HIF-1 $\beta$ expression [51].

In CRC cell lines, miR-145 expression is reduced and can directly regulate p70S6K1 expression by binding its 3'-UTR. Since HIF1- $\alpha$ and VEGF are downstream targets of p70S6K1, miR-145 overexpression can suppress CRC growth and angiogenesis by decreasing HIF- $1 \alpha$ and VEGF expression. Correlation analysis revealed that miR-145 expression is negatively correlated with p70S6K1, suggesting that miR-145 acts as a tumor suppressor in CRC [52]. Under hypoxic conditions, autophagy is induced and is related to CRC metastasis and EMT. Expression of the lncRNA CPS1-IT1 is significantly reduced in CRC tissues and cell lines, with in vitro analysis revealing that CPS1-IT1 overexpression suppresses EMT and autophagy by inhibiting HIF- $1 \alpha$ activation. The regulation of CRC metastasis by autophagy under hypoxic conditions may therefore be associated with CPS1-IT1 acting as a tumor suppressor [53].

\subsection{HIFs Regulate ncRNA Expression in CRC}

Under hypoxic conditions, tumor cells modify their energy sources to maintain malignant proliferation [8]. MiR-23a, miR-27a, and miR-24 are significantly overexpressed in CRC due to direct regulation by HIF- $1 \alpha$, which binds the HRE1 and HRE2 sites of the miR-23a 27a 24 cluster under hypoxic conditions. HIF- $1 \alpha$ induction of the miR-23a $27 a \sim 24$ cluster is critically associated with the glucose metabolic pathway as it controls TCA-related genes and metabolic pathways in CRC cell lines, suggesting that this mechanism may be an important metabolic switch in CRC metabolism [54].

In cancer, hypoxia-induced autophagy can lead to radioresistance [55]. Under hypoxic conditions, HIF- $1 \alpha$ overexpression positively regulates miR-210 expression, which induces autophagy by inhibiting $\mathrm{Bcl}-2$ expression, thus reducing radiosensitivity in CRC [56]. MiRNAs are strongly involved in the acquisition of drug resistance in CRC [57]. Under hypoxic conditions, HIF-1 $\alpha$ mediates miR-338-5p downregulation, which is associated with hypoxia-induced drug resistance by regulating its direct target, IL-6. Furthermore, miR-338-5p overexpression and HIF-1 $\alpha$ inhibitors have been shown to reduce CRC drug resistance to oxaliplatin in vivo [58].

Expression of the lncRNA HOTAIR is directly regulated by HIF- $1 \alpha$ binding to its HRE site, while MLL1 (a histone methyltransferase) and p300 (a histone acetyltransferase) are epigenetically enriched at the HOTAIR promoter under hypoxic conditions, suggesting that both MLL1 and p300 coordination, as well as HIF- $1 \alpha$, are involved in the regulation of HOTAIR under hypoxia in CRC [59]. MiR-15-16 expression is regulated by hypoxia-induced repression in CRC. In advanced stage tumors, HIF- $2 \alpha$ induces c-Myc to repress miR-15-16, which promotes tumor metastasis and angiogenesis by downregulating FGF2, a direct target of miR-15-16 [60]. There are no more literatures about HIF- $2 \alpha$-related ncRNA in CRC as well as GC, but a few studies have been reported to a lesser extent than HIF- $1 \alpha$ in other cancers. For instance, miR-145 suppresses HIF-2 $\alpha$ expression through targeting 3'-UTR of HIF-2 $\alpha$ in neuroblastoma [61], and induction of NRAT1 lncRNA expression by HIF-2 $\alpha$ leads to increase in cell proliferation in hypoxic breast cancer [62]. HIF-related ncRNAs in CRC are summarized in Table 2. 
Table 2. HIF-related ncRNAs in colorectal cancer (CRC).

\begin{tabular}{|c|c|c|c|}
\hline Non-coding RNAs & Functions & Targets & Ref. \\
\hline miR-210, miR-21 & $\begin{array}{l}\text { Regulates HIF-1 } \alpha \text { / VEGF signaling pathways to } \\
\text { initiate colon cancer. }\end{array}$ & & [45] \\
\hline $\mathrm{miR}-200 \mathrm{~b}$ & $\begin{array}{l}\text { Directly regulates HIF- } 1 \alpha \text { and regulatory feedback } \\
\text { for CRC EMT-MET plasticity. }\end{array}$ & HIF- $1 \alpha$ & [46] \\
\hline miR-199a & $\begin{array}{l}\text { Reduces HIF-1 } \alpha / \text { VEGF expression and suppresses } \\
\text { CRC proliferation, migration, and invasion. }\end{array}$ & & [47] \\
\hline miR-31 & $\begin{array}{l}\text { Reduces FIH expression and is associated with } \\
\text { CRC development. }\end{array}$ & FIH-1 & [49] \\
\hline $\operatorname{miR}-22$ & $\begin{array}{c}\text { Down-regulates HIF- } 1 \alpha \text { and represses cell growth } \\
\text { and invasion in CRC. }\end{array}$ & HIF-1 $\alpha$ & [50] \\
\hline miR-107 & $\begin{array}{l}\text { Reduces HIF- } 1 \beta \text { expression and down-regulates } \\
\text { tumor growth, VEGF expression, and angiogenesis. }\end{array}$ & HIF- $1 \beta$ & [51] \\
\hline $\operatorname{miR}-145$ & $\begin{array}{l}\text { Down-regulates HIF-1 } \alpha \text { and VEGF expression and } \\
\text { represses cell growth and angiogenesis in CRC. }\end{array}$ & p70S6K1 & [52] \\
\hline lncRNA CPS1-IT1 & $\begin{array}{l}\text { Inhibits HIF-1 } \alpha \text { activation and suppresses EMT } \\
\text { and autophagy. }\end{array}$ & & [53] \\
\hline miR-23a, miR27a, miR-24 & $\begin{array}{c}\text { Regulates glucose association via TCA-related } \\
\text { genes under hypoxic conditions (HRE1, HRE2 in } \\
\text { miRNA promoter }{ }^{1} \text { ). }\end{array}$ & & [54] \\
\hline $\operatorname{miR}-210$ & $\begin{array}{l}\text { Reduces radiosensitivity by inducing autophagy in } \\
\text { CRC. }\end{array}$ & Bcl-2 & [56] \\
\hline $\operatorname{miR}-338-5 p$ & $\begin{array}{c}\text { Reduces hypoxia-induced drug resistance by } \\
\text { regulating IL-6. }\end{array}$ & IL-6 & [58] \\
\hline lncRNA HOTAIR & $\begin{array}{l}\text { Regulates tumor growth under hypoxic conditions } \\
\left.\text { in CRC (HRE region in lncRNA promoter }{ }^{1}\right) \text {. }\end{array}$ & & [59] \\
\hline miR-15-16 & $\begin{array}{l}\text { Regulates tumor metastasis and angiogenesis } \\
\text { (Indirect target of HIF- } 2 \alpha^{1} \text { ). }\end{array}$ & FGF-2 & [60] \\
\hline
\end{tabular}

\section{Prospective Therapeutic Applications of ncRNAs as HIF Regulators}

It has been well established that HIFs exert tumorigenic effects in the tumor microenvironment, including regulating cell metabolism, proliferation, invasion, metastasis, angiogenesis, and resistance to chemo- and radiotherapy $[9,63,64]$. Therefore, HIFs are an attractive target for anti-cancer drugs that act specifically on hypoxic cancer cells. Considerable effort has been put into developing HIF regulators, with several inhibitors having entered clinical trials to treat a variety of cancers [65].

The HIF- $1 \alpha$ inhibitor digoxin, which exerts anti-cancer effects by reducing the protein levels of HIF- $1 \alpha$ and its target genes (GLUT1, HK, and VEGF [66]) is currently in phase II clinical trials to treat several cancers, including head and neck cancer, Kaposi's sarcoma, and breast cancer [67]. The first-in-class HIF- $2 \alpha$ inhibitors PT2385 and PT2977 reduce the hypoxia-induced expression of VEGF and other hypoxia-responsible genes by blocking HIF- $2 \alpha$ dimerization and DNA binding $[68,69]$. These inhibitors are currently under evaluation in a phase I/II clinical trial for treating VHL-associated renal carcinoma (RCC) and advanced clear cell RCC [70,71].

Although small molecules have been widely developed as HIF regulators, many recent studies have proposed the use of miRNA-based approaches for regulating HIFs [72]. The detailed mechanisms via which miRNAs control HIF- $1 \alpha$ expression can be divided into direct and indirect regulation. Most miRNAs, including miR-18a, miR-186, miR-143, miR-200b, and miR-22, suppress HIF-1 $\alpha$ expression in GC by binding directly to its 3'-UTR in an oxygen-independent manner. Conversely, the indirect regulation of HIF- $1 \alpha$ protein levels by miRNAs is an oxygen-dependent process. For instance, miR-182 reduces PHD expression by targeting its 3'-UTR, thus stabilizing HIF-1 $\alpha$ proteins in prostate cancer [73]. FIH-1 is another miRNA that indirectly regulates HIF- $1 \alpha$; in response to oxygen, FIH-1 hydroxylates Asp803 in the HIF-1 $\alpha$ C-terminal transcription activation domain, blocking the 
recruitment of its co-activator p300 and inactivating its transcriptional activity. Enhanced miR-31 expression reduces FIH-1 expression by binding its 3'-UTR and inducing HIF-1 $\alpha$ activation [49] in head and neck carcinoma [74]. Therefore, both the direct and indirect mechanisms of HIF regulation are potential therapeutic targets for treating cancer.

It is well known that activating HIF signaling results in resistance to chemo- and radiotherapy in hypoxic cancer cells [75]. As mentioned previously, HIF-1 $\alpha$ suppresses Bcl-2 expression in colon cancer cells by inducing miR-210 expression, resulting in autophagy activation and radioresistance [56]. MiR-210-induced radioresistance has also been reported in other cancer cells under hypoxic conditions, such as hepatocellular cancer cells [76] and glioma stem cells [77]. In addition, chemotherapy resistance is also associated with miRNA expression levels. In colorectal cancer, enhancing miR-31 expression using 5-FU, one of the most common anticancer drugs, can promote chemoresistance [78]. Since miR-31 directly suppresses FIH-1 expression [49], these studies suggest that HIF- $1 \alpha$ is strongly involved in miR-31-mediated resistance. Furthermore, miR-31-specific oligonucleotides increase the 5-FU sensitivity of HCT116 colon cancer cells [79]. Therefore, miR-210 and miR-31 might both be attractive therapeutic targets to increase the sensitivity of hypoxic cancer cells to radiotherapy and chemotherapy.

Cancer immunotherapies that target immune checkpoints have been identified as promising cancer treatments; for instance, immune checkpoint-blocking monoclonal antibodies such as cytotoxic T-lymphocyte associated antigen (CTLA)-4 and programed death (PD)-1 have been approved by the Food and Drug Administration (FDA) to treat various cancers $[80,81]$. Under hypoxic conditions, HIF- $1 \alpha$ enhances the expression of PD-1 ligand (PD-L1) on the surface of cancer cells by directly binding to the HRE in the PD-L1 promoter $[82,83]$. In addition, HIF-2 $\alpha$ induces PD-L1 expression in VHL-deficient clear cell RCC cells [84,85], indicating that HIF- $1 \alpha$ and $-2 \alpha$ inhibition could sensitize cells to anti-PD-L1 therapy by downregulating PD-L1. Based on these findings, miRNAs that reduce HIF expression, such as miR-18a, miR-186, miR-143, miR-210, miR-21, miR-22, and miR-145, may also overcome the PD-L1-mediated immune escape of cancer cells in gastrointestinal cancers. Furthermore, miRNAs such as miR-570, miR-513, miR-197, miR-34a, and miR-200 have been found to negatively regulate PD-L1 expression at the post-transcriptional level by binding its $3^{\prime}$-UTR $[86,87]$. Thus, combining these miRNAs with HIF inhibitors could provide prospective PD-1/PD-L1-based cancer immunotherapies.

\section{Summary}

Here, we reviewed the roles of HIFs and ncRNAs in GI cancers. Various ncRNAs are involved in hypoxia-mediated cellular processes, including the regulation of HIF- $1 \alpha$ expression, proliferation, angiogenesis, metastasis, and chemoresistance; thus, may be useful therapeutic targets or diagnostic biomarkers (Figure 1). Recently, there has been growing concern about cancer metabolism drugs that target the metabolic processes of cancer cells, such as aerobic glycolysis, mitochondrial metabolism, and energy utilization. Since HIFs play a central role in hypoxia-specific cancer metabolism, ncRNAs that downregulate HIF signaling combined with HIF inhibitors could be considered as novel cancer metabolic therapy strategies. 


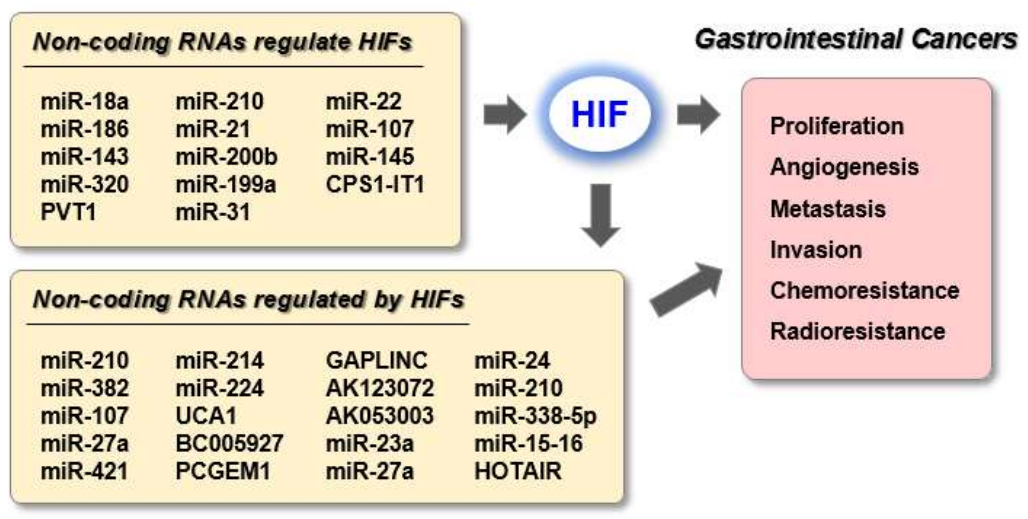

Figure 1. Summary for HIF-related ncRNAs in gastrointestinal cancers.

Author Contributions: writing—original draft preparation, H.-S.C. and T.H.; writing—review and editing, K.H.; writing-editing and visualization, H.S.B.

Funding: This study was supported by grants from the National Research Foundation of Korea (NRF) funded by the Ministry of Science and ICT (NRF-2017R1C1B2012268, 2018M3A9H3023077, 2019R1A2C1083892, 2019R1I1A2A01060951) and the KRIBB Research Initiative Program.

Conflicts of Interest: The authors declare no conflict of interest.

\section{References}

1. Sitarz, R.; Skierucha, M.; Mielko, J.; Offerhaus, G.J.A.; Maciejewski, R.; Polkowski, W.P. Gastric cancer: Epidemiology, prevention, classification, and treatment. Cancer Manag. Res. 2018, 10, 239-248. [CrossRef] [PubMed]

2. Wilson, W.R.; Hay, M.P. Targeting hypoxia in cancer therapy. Nat. Rev. Cancer 2011, 11, 393-410. [CrossRef] [PubMed]

3. Hirose, K.; Morita, M.; Ema, M.; Mimura, J.; Hamada, H.; Fujii, H.; Saijo, Y.; Gotoh, O.; Sogawa, K.; Fujii-Kuriyama, Y. cDNA cloning and tissue-specific expression of a novel basic helix-loop-helix/PAS factor (Arnt2) with close sequence similarity to the aryl hydrocarbon receptor nuclear translocator (Arnt). Mol. Cell. Biol. 1996, 16, 1706-1713. [CrossRef] [PubMed]

4. Wang, G.L.; Jiang, B.H.; Rue, E.A.; Semenza, G.L. Hypoxia-inducible factor 1 is a basic-helix-loop-helix-PAS heterodimer regulated by cellular O2 tension. Proc. Natl. Acad. Sci. USA 1995, 92, 5510-5514. [CrossRef] [PubMed]

5. Maxwell, P.H.; Wiesener, M.S.; Chang, G.W.; Clifford, S.C.; Vaux, E.C.; Cockman, M.E.; Wykoff, C.C.; Pugh, C.W.; Maher, E.R.; Ratcliffe, P.J. The tumour suppressor protein VHL targets hypoxia-inducible factors for oxygen-dependent proteolysis. Nature 1999, 399, 271-275. [CrossRef] [PubMed]

6. Semenza, G.L.; Nejfelt, M.K.; Chi, S.M.; Antonarakis, S.E. Hypoxia-inducible nuclear factors bind to an enhancer element located 3' to the human erythropoietin gene. Proc. Natl. Acad. Sci. USA 1991, 88, 5680-5684. [CrossRef] [PubMed]

7. Denko, N.C. Hypoxia, HIF1 and glucose metabolism in the solid tumour. Nat. Rev. Cancer 2008, 8, 705-713. [CrossRef]

8. Majmundar, A.J.; Wong, W.J.; Simon, M.C. Hypoxia-inducible factors and the response to hypoxic stress. Mol. Cell 2010, 40, 294-309. [CrossRef]

9. Semenza, G.L. Targeting HIF-1 for cancer therapy. Nat. Rev. Cancer 2003, 3, 721-732. [CrossRef]

10. Schito, L.; Semenza, G.L. Hypoxia-Inducible Factors: Master Regulators of Cancer Progression. Trends Cancer 2016, 2, 758-770. [CrossRef]

11. Zhong, H.; De Marzo, A.M.; Laughner, E.; Lim, M.; Hilton, D.A.; Zagzag, D.; Buechler, P.; Isaacs, W.B.; Semenza, G.L.; Simons, J.W. Overexpression of hypoxia-inducible factor 1alpha in common human cancers and their metastases. Cancer Res. 1999, 59, 5830-5835. [PubMed]

12. Lee, Y.; Kim, M.; Han, J.; Yeom, K.H.; Lee, S.; Baek, S.H.; Kim, V.N. MicroRNA genes are transcribed by RNA polymerase II. EMBO J. 2004, 23, 4051-4060. [CrossRef] [PubMed] 
13. Macfarlane, L.A.; Murphy, P.R. MicroRNA: Biogenesis, Function and Role in Cancer. Curr Genom. 2010, 11, 537-561. [CrossRef] [PubMed]

14. Ha, M.; Kim, V.N. Regulation of microRNA biogenesis. Nat. Rev. Mol. Cell Biol. 2014, 15, 509-524. [CrossRef]

15. Lee, R.C.; Feinbaum, R.L.; Ambros, V. The C. elegans heterochronic gene lin-4 encodes small RNAs with antisense complementarity to lin-14. Cell 1993, 75, 843-854. [CrossRef]

16. Reinhart, B.J.; Slack, F.J.; Basson, M.; Pasquinelli, A.E.; Bettinger, J.C.; Rougvie, A.E.; Horvitz, H.R.; Ruvkun, G. The 21-nucleotide let-7 RNA regulates developmental timing in Caenorhabditis elegans. Nature 2000, 403, 901-906. [CrossRef]

17. Iyer, M.K.; Niknafs, Y.S.; Malik, R.; Singhal, U.; Sahu, A.; Hosono, Y.; Barrette, T.R.; Prensner, J.R.; Evans, J.R.; Zhao, S.; et al. The landscape of long noncoding RNAs in the human transcriptome. Nat. Genet. 2015, 47, 199-208. [CrossRef]

18. Wang, K.C.; Chang, H.Y. Molecular mechanisms of long noncoding RNAs. Mol. Cell 2011, 43, 904-914. [CrossRef]

19. Schmitt, A.M.; Chang, H.Y. Long Noncoding RNAs in Cancer Pathways. Cancer Cell 2016, $29,452-463$. [CrossRef]

20. Bartonicek, N.; Maag, J.L.; Dinger, M.E. Long noncoding RNAs in cancer: Mechanisms of action and technological advancements. Mol. Cancer 2016, 15, 43. [CrossRef]

21. Bhan, A.; Soleimani, M.; Mandal, S.S. Long Noncoding RNA and Cancer: A New Paradigm. Cancer Res. 2017, 77, 3965-3981. [CrossRef] [PubMed]

22. Zhang, R.; Xia, L.Q.; Lu, W.W.; Zhang, J.; Zhu, J.S. LncRNAs and cancer. Oncol. Lett. 2016, 12, $1233-1239$. [CrossRef] [PubMed]

23. Wu, F.; Huang, W.; Wang, X. microRNA-18a regulates gastric carcinoma cell apoptosis and invasion by suppressing hypoxia-inducible factor-1alpha expression. Exp. Ther. Med. 2015, 10, 717-722. [CrossRef] [PubMed]

24. Liu, L.; Wang, Y.; Bai, R.; Yang, K.; Tian, Z. MiR-186 inhibited aerobic glycolysis in gastric cancer via HIF-1alpha regulation. Oncogenesis 2016, 5, e224. [CrossRef] [PubMed]

25. Wu, F.; Gao, H.; Liu, K.; Gao, B.; Ren, H.; Li, Z.; Liu, F. The lncRNA ZEB2-AS1 is upregulated in gastric cancer and affects cell proliferation and invasion via miR-143-5p/HIF-1alpha axis. OncoTargets Ther. 2019, 12, 657-667. [CrossRef] [PubMed]

26. Zhang, X.W.; Bu, P.; Liu, L.; Zhang, X.Z.; Li, J. Overexpression of long non-coding RNA PVT1 in gastric cancer cells promotes the development of multidrug resistance. Biochem. Biophys. Res. Commun. 2015, 462, 227-232. [CrossRef]

27. Huang, T.; Liu, H.W.; Chen, J.Q.; Wang, S.H.; Hao, L.Q.; Liu, M.; Wang, B. The long noncoding RNA PVT1 functions as a competing endogenous RNA by sponging miR-186 in gastric cancer. Biomed. Pharmacother. 2017, 88, 302-308. [CrossRef]

28. Zhou, Y.; Xu, Q.; Shang, J.; Lu, L.; Chen, G. Crocin inhibits the migration, invasion, and epithelial-mesenchymal transition of gastric cancer cells via miR-320/KLF5/HIF-1alpha signaling. J. Cell. Physiol. 2019, 234, 17876-17885. [CrossRef]

29. Yu, P.; Fan, S.; Huang, L.; Yang, L.; Du, Y. MIR210 as a potential molecular target to block invasion and metastasis of gastric cancer. Med. Hypotheses 2015, 84, 209-212. [CrossRef]

30. Chen, K.C.; Liao, Y.C.; Wang, J.Y.; Lin, Y.C.; Chen, C.H.; Juo, S.H. Oxidized low-density lipoprotein is a common risk factor for cardiovascular diseases and gastroenterological cancers via epigenomical regulation of microRNA-210. Oncotarget 2015, 6, 24105-24118. [CrossRef]

31. Zhang, C.; Tian, W.; Meng, L.; Qu, L.; Shou, C. PRL-3 promotes gastric cancer migration and invasion through a NF-kappaB-HIF-1alpha-miR-210 axis. J. Mol. Med. 2016, 94, 401-415. [CrossRef] [PubMed]

32. Seok, J.K.; Lee, S.H.; Kim, M.J.; Lee, Y.M. MicroRNA-382 induced by HIF-1alpha is an angiogenic miR targeting the tumor suppressor phosphatase and tensin homolog. Nucleic Acids Res. 2014, 42, 8062-8072. [CrossRef] [PubMed]

33. Seo, A.N.; Jung, Y.; Jang, H.; Lee, E.; Bae, H.I.; Son, T.; Kwon, O.; Chung, H.Y.; Yu, W.; Lee, Y.M. Clinical significance and prognostic role of hypoxia-induced microRNA 382 in gastric adenocarcinoma. PLoS ONE 2019, 14, e0223608. [CrossRef] [PubMed] 
34. Ayremlou, N.; Mozdarani, H.; Mowla, S.J.; Delavari, A. Increased levels of serum and tissue miR-107 in human gastric cancer: Correlation with tumor hypoxia. Cancer Biomark. 2015, 15, 851-860. [CrossRef] [PubMed]

35. Zhao, Q.; Li, Y.; Tan, B.B.; Fan, L.Q.; Yang, P.G.; Tian, Y. HIF-1alpha Induces Multidrug Resistance in Gastric Cancer Cells by Inducing MiR-27a. PLoS ONE 2015, 10, e0132746. [CrossRef]

36. Ge, X.; Liu, X.; Lin, F.; Li, P.; Liu, K.; Geng, R.; Dai, C.; Lin, Y.; Tang, W.; Wu, Z.; et al. MicroRNA-421 regulated by HIF-1alpha promotes metastasis, inhibits apoptosis, and induces cisplatin resistance by targeting E-cadherin and caspase-3 in gastric cancer. Oncotarget 2016, 7, 24466-24482. [CrossRef]

37. He, C.; Wang, L.; Zhang, J.; Xu, H. Hypoxia-inducible microRNA-224 promotes the cell growth, migration and invasion by directly targeting RASSF8 in gastric cancer. Mol. Cancer 2017, 16, 35. [CrossRef]

38. Yang, L.; Zhang, W.; Wang, Y.; Zou, T.; Zhang, B.; Xu, Y.; Pang, T.; Hu, Q.; Chen, M.; Wang, L.; et al. Hypoxia-induced miR-214 expression promotes tumour cell proliferation and migration by enhancing the Warburg effect in gastric carcinoma cells. Cancer Lett. 2018, 414, 44-56. [CrossRef]

39. Yang, Z.; Shi, X.; Li, C.; Wang, X.; Hou, K.; Li, Z.; Zhang, X.; Fan, Y.; Qu, X.; Che, X.; et al. Long non-coding RNA UCA1 upregulation promotes the migration of hypoxia-resistant gastric cancer cells through the miR-7-5p/EGFR axis. Exp. Cell Res. 2018, 368, 194-201. [CrossRef]

40. Liu, X.; Wang, Y.; Sun, L.; Min, J.; Liu, J.; Chen, D.; Zhang, H.; Zhang, H.; Zhang, H.; Zhou, Y.; et al. Long noncoding RNA BC005927 upregulates EPHB4 and promotes gastric cancer metastasis under hypoxia. Cancer Sci. 2018, 109, 988-1000. [CrossRef]

41. Zhang, J.; Jin, H.Y.; Wu, Y.; Zheng, Z.C.; Guo, S.; Wang, Y.; Yang, D.; Meng, X.Y.; Xu, X.; Zhao, Y. Hypoxia-induced LncRNA PCGEM1 promotes invasion and metastasis of gastric cancer through regulating SNAI1. Clin. Transl Oncol. 2019, 21, 1142-1151. [CrossRef] [PubMed]

42. Liu, L.; Zhao, X.; Zou, H.; Bai, R.; Yang, K.; Tian, Z. Hypoxia Promotes Gastric Cancer Malignancy Partly through the HIF-1alpha Dependent Transcriptional Activation of the Long Non-coding RNA GAPLINC. Front. Physiol. 2016, 7, 420. [CrossRef] [PubMed]

43. Yang, Z.; Wang, R.; Zhang, T.; Dong, X. Hypoxia/lncRNA-AK123072/EGFR pathway induced metastasis and invasion in gastric cancer. Int J. Clin. Exp. Med. 2015, 8, 19954-19968. [PubMed]

44. Wang, Y.; Liu, X.; Zhang, H.; Sun, L.; Zhou, Y.; Jin, H.; Zhang, H.; Zhang, H.; Liu, J.; Guo, H.; et al. Hypoxia-inducible lncRNA-AK058003 promotes gastric cancer metastasis by targeting gamma-synuclein. Neoplasia 2014, 16, 1094-1106. [CrossRef] [PubMed]

45. Sabry, D.; El-Deek, S.E.M.; Maher, M.; El-Baz, M.A.H.; El-Bader, H.M.; Amer, E.; Hassan, E.A.; Fathy, W.; El-Deek, H.E.M. Role of miRNA-210, miRNA-21 and miRNA-126 as diagnostic biomarkers in colorectal carcinoma: Impact of HIF-1alpha-VEGF signaling pathway. Mol. Cell Biochem. 2019, 454, 177-189. [CrossRef]

46. Shang, Y.; Chen, H.; Ye, J.; Wei, X.; Liu, S.; Wang, R. HIF-1alpha/Ascl2/miR-200b regulatory feedback circuit modulated the epithelial-mesenchymal transition (EMT) in colorectal cancer cells. Exp. Cell Res. 2017, 360, 243-256. [CrossRef]

47. Ye, H.; Pang, L.; Wu, Q.; Zhu, Y.; Guo, C.; Deng, Y.; Zheng, X. A critical role of mir-199a in the cell biological behaviors of colorectal cancer. Diagn Pathol. 2015, 10, 65. [CrossRef]

48. Couvelard, A.; Deschamps, L.; Rebours, V.; Sauvanet, A.; Gatter, K.; Pezzella, F.; Ruszniewski, P.; Bedossa, P. Overexpression of the oxygen sensors PHD-1, PHD-2, PHD-3, and FIH Is associated with tumor aggressiveness in pancreatic endocrine tumors. Clin. Cancer Res. 2008, 14, 6634-6639. [CrossRef]

49. Chen, T.; Yao, L.Q.; Shi, Q.; Ren, Z.; Ye, L.C.; Xu, J.M.; Zhou, P.H.; Zhong, Y.S. MicroRNA-31 contributes to colorectal cancer development by targeting factor inhibiting HIF-1alpha (FIH-1). Cancer Biol. Ther. 2014, 15, 516-523. [CrossRef]

50. Yamakuchi, M.; Yagi, S.; Ito, T.; Lowenstein, C.J. MicroRNA-22 regulates hypoxia signaling in colon cancer cells. PLoS ONE 2011, 6, e20291. [CrossRef]

51. Yamakuchi, M.; Lotterman, C.D.; Bao, C.; Hruban, R.H.; Karim, B.; Mendell, J.T.; Huso, D.; Lowenstein, C.J. P53-induced microRNA-107 inhibits HIF-1 and tumor angiogenesis. Proc. Natl. Acad. Sci. USA 2010, 107, 6334-6339. [CrossRef] [PubMed]

52. Xu, Q.; Liu, L.Z.; Qian, X.; Chen, Q.; Jiang, Y.; Li, D.; Lai, L.; Jiang, B.H. MiR-145 directly targets p70S6K1 in cancer cells to inhibit tumor growth and angiogenesis. Nucleic Acids Res. 2012, 40, 761-774. [CrossRef] [PubMed] 
53. Zhang, W.; Yuan, W.; Song, J.; Wang, S.; Gu, X. LncRNA CPS1-IT1 suppresses EMT and metastasis of colorectal cancer by inhibiting hypoxia-induced autophagy through inactivation of HIF-1alpha. Biochimie 2018, 144, 21-27. [CrossRef] [PubMed]

54. Jin, F.; Yang, R.; Wei, Y.; Wang, D.; Zhu, Y.; Wang, X.; Lu, Y.; Wang, Y.; Zen, K.; Li, L. HIF-1alpha-induced miR-23a approximately 27a approximately 24 cluster promotes colorectal cancer progression via reprogramming metabolism. Cancer Lett. 2019, 440-441, 211-222. [CrossRef]

55. He, W.S.; Dai, X.F.; Jin, M.; Liu, C.W.; Rent, J.H. Hypoxia-induced autophagy confers resistance of breast cancer cells to ionizing radiation. Oncol. Res. 2012, 20, 251-258. [CrossRef]

56. Sun, Y.; Xing, X.; Liu, Q.; Wang, Z.; Xin, Y.; Zhang, P.; Hu, C.; Liu, Y. Hypoxia-induced autophagy reduces radiosensitivity by the HIF-1alpha/miR-210/Bcl-2 pathway in colon cancer cells. Int. J. Oncol. 2015, 46, 750-756. [CrossRef]

57. Ayers, D.; Vandesompele, J. Influence of microRNAs and Long Non-Coding RNAs in Cancer Chemoresistance. Genes 2017, 8, 95. [CrossRef]

58. Xu, K.; Zhan, Y.; Yuan, Z.; Qiu, Y.; Wang, H.; Fan, G.; Wang, J.; Li, W.; Cao, Y.; Shen, X.; et al. Hypoxia Induces Drug Resistance in Colorectal Cancer through the HIF-1alpha/miR-338-5p/IL-6 Feedback Loop. Mol. Ther. 2019, 27, 1810-1824. [CrossRef]

59. Bhan, A.; Deb, P.; Shihabeddin, N.; Ansari, K.I.; Brotto, M.; Mandal, S.S. Histone methylase MLL1 coordinates with HIF and regulate lncRNA HOTAIR expression under hypoxia. Gene 2017, 629, 16-28. [CrossRef]

60. Xue, G.; Yan, H.L.; Zhang, Y.; Hao, L.Q.; Zhu, X.T.; Mei, Q.; Sun, S.H. c-Myc-mediated repression of miR-15-16 in hypoxia is induced by increased HIF-2alpha and promotes tumor angiogenesis and metastasis by upregulating FGF2. Oncogene 2015, 34, 1393-1406. [CrossRef]

61. Zhang, H.; Pu, J.; Qi, T.; Qi, M.; Yang, C.; Li, S.; Huang, K.; Zheng, L.; Tong, Q. MicroRNA-145 inhibits the growth, invasion, metastasis and angiogenesis of neuroblastoma cells through targeting hypoxia-inducible factor 2 alpha. Oncogene 2014, 33, 387-397. [CrossRef] [PubMed]

62. Choudhry, H.; Albukhari, A.; Morotti, M.; Haider, S.; Moralli, D.; Smythies, J.; Schödel, J.; Green, C.M.; Camps, C.; Buffa, F.; et al. Tumor hypoxia induces nuclear paraspeckle formation through HIF-2 $\alpha$ dependent transcriptional activation of NEAT1 leading to cancer cell survival. Oncogene 2015, 34, 4482-4490. [CrossRef] [PubMed]

63. Rankin, E.B.; Giaccia, A.J. The role of hypoxia-inducible factors in tumorigenesis. Cell Death Differ. 2008, 15, 678-685. [CrossRef] [PubMed]

64. Petrova, V.; Annicchiarico-Petruzzelli, M.; Melino, G.; Amelio, I. The hypoxic tumour microenvironment. Oncogenesis 2018, 7, 10. [CrossRef] [PubMed]

65. Fallah, J.; Rini, B.I. HIF Inhibitors: Status of Current Clinical Development. Curr. Oncol. Rep. 2019, $21,6$. [CrossRef]

66. Zhang, H.; Qian, D.Z.; Tan, Y.S.; Lee, K.; Gao, P.; Ren, Y.R.; Rey, S.; Hammers, H.; Chang, D.; Pili, R.; et al. Digoxin and other cardiac glycosides inhibit HIF-1alpha synthesis and block tumor growth. Proc. Natl. Acad. Sci. USA 2008, 105, 19579-19586. [CrossRef]

67. DiGiacomo, J.W.; Gilkes, D.M. Therapeutic Strategies to Block the Hypoxic Response. Adv. Exp. Med. Biol. 2019, 1136, 141-157. [CrossRef]

68. Wallace, E.M.; Rizzi, J.P.; Han, G.; Wehn, P.M.; Cao, Z.; Du, X.; Cheng, T.; Czerwinski, R.M.; Dixon, D.D.; Goggin, B.S.; et al. A Small-Molecule Antagonist of HIF2alpha Is Efficacious in Preclinical Models of Renal Cell Carcinoma. Cancer Res. 2016, 76, 5491-5500. [CrossRef]

69. Xu, R.; Wang, K.; Rizzi, J.P.; Huang, H.; Grina, J.A.; Schlachter, S.T.; Wang, B.; Wehn, P.M.; Yang, H.; Dixon, D.D.; et al. 3-[(1S,2S,3R)-2,3-Difluoro-1-hydroxy-7-methylsulfonylindan-4-yl]oxy-5-fluorobenzo nitrile (PT2977), a Hypoxia-Inducible Factor 2alpha (HIF-2alpha) Inhibitor for the Treatment of Clear Cell Renal Cell Carcinoma. J. Med. Chem. 2019, 62, 6876-6893. [CrossRef]

70. Courtney, K.D.; Infante, J.R.; Lam, E.T.; Figlin, R.A.; Rini, B.I.; Brugarolas, J.; Zojwalla, N.J.; Lowe, A.M.; Wang, K.; Wallace, E.M.; et al. Phase I Dose-Escalation Trial of PT2385, a First-in-Class Hypoxia-Inducible Factor-2alpha Antagonist in Patients With Previously Treated Advanced Clear Cell Renal Cell Carcinoma. J. Clin. Oncol. Off. J. Am. Soc. Clin. Oncol. 2018, 36, 867-874. [CrossRef]

71. Yu, Y.; Yu, Q.; Zhang, X. Allosteric inhibition of HIF-2alpha as a novel therapy for clear cell renal cell carcinoma. Drug Discov. Today 2019, 10. 
72. Serocki, M.; Bartoszewska, S.; Janaszak-Jasiecka, A.; Ochocka, R.J.; Collawn, J.F.; Bartoszewski, R. miRNAs regulate the HIF switch during hypoxia: A novel therapeutic target. Angiogenesis 2018, 21, 183-202. [CrossRef] [PubMed]

73. Li, Y.; Zhang, D.; Wang, X.; Yao, X.; Ye, C.; Zhang, S.; Wang, H.; Chang, C.; Xia, H.; Wang, Y.C.; et al. Hypoxia-inducible miR-182 enhances HIF1alpha signaling via targeting PHD2 and FIH1 in prostate cancer. Sci. Rep. 2015, 5, 12495. [CrossRef] [PubMed]

74. Liu, C.J.; Tsai, M.M.; Hung, P.S.; Kao, S.Y.; Liu, T.Y.; Wu, K.J.; Chiou, S.H.; Lin, S.C.; Chang, K.W. miR-31 ablates expression of the HIF regulatory factor FIH to activate the HIF pathway in head and neck carcinoma. Cancer Res. 2010, 70, 1635-1644. [CrossRef] [PubMed]

75. Xia, Y.; Jiang, L.; Zhong, T. The role of HIF-1alpha in chemo-/radioresistant tumors. OncoTargets Ther. 2018, 11, 3003-3011. [CrossRef]

76. Yang, W.; Sun, T.; Cao, J.; Liu, F.; Tian, Y.; Zhu, W. Downregulation of miR-210 expression inhibits proliferation, induces apoptosis and enhances radiosensitivity in hypoxic human hepatoma cells in vitro. Exp. Cell Res. 2012, 318, 944-954. [CrossRef]

77. Yang, W.; Wei, J.; Guo, T.; Shen, Y.; Liu, F. Knockdown of miR-210 decreases hypoxic glioma stem cells stemness and radioresistance. Exp. Cell Res. 2014, 326, 22-35. [CrossRef]

78. Nakagawa, Y.; Kuranaga, Y.; Tahara, T.; Yamashita, H.; Shibata, T.; Nagasaka, M.; Funasaka, K.; Ohmiya, N.; Akao, Y. Induced miR-31 by 5-fluorouracil exposure contributes to the resistance in colorectal tumors. Cancer Sci. 2019, 110, 2540-2548. [CrossRef]

79. Wang, C.J.; Stratmann, J.; Zhou, Z.G.; Sun, X.F. Suppression of microRNA-31 increases sensitivity to 5-FU at an early stage, and affects cell migration and invasion in HCT-116 colon cancer cells. BMC Cancer 2010, 10, 616. [CrossRef]

80. Ribas, A.; Wolchok, J.D. Cancer immunotherapy using checkpoint blockade. Science 2018, 359, $1350-1355$. [CrossRef]

81. Wei, S.C.; Duffy, C.R.; Allison, J.P. Fundamental Mechanisms of Immune Checkpoint Blockade Therapy. Cancer Discov. 2018, 8, 1069-1086. [CrossRef] [PubMed]

82. Noman, M.Z.; Desantis, G.; Janji, B.; Hasmim, M.; Karray, S.; Dessen, P.; Bronte, V.; Chouaib, S. PD-L1 is a novel direct target of HIF-1alpha, and its blockade under hypoxia enhanced MDSC-mediated T cell activation. J. Exp. Med. 2014, 211, 781-790. [CrossRef] [PubMed]

83. Barsoum, I.B.; Smallwood, C.A.; Siemens, D.R.; Graham, C.H. A mechanism of hypoxia-mediated escape from adaptive immunity in cancer cells. Cancer Res. 2014, 74, 665-674. [CrossRef] [PubMed]

84. Ruf, M.; Moch, H.; Schraml, P. PD-L1 expression is regulated by hypoxia inducible factor in clear cell renal cell carcinoma. Int. J. Cancer 2016, 139, 396-403. [CrossRef] [PubMed]

85. Messai, Y.; Gad, S.; Noman, M.Z.; Le Teuff, G.; Couve, S.; Janji, B.; Kammerer, S.F.; Rioux-Leclerc, N.; Hasmim, M.; Ferlicot, S.; et al. Renal Cell Carcinoma Programmed Death-ligand 1, a New Direct Target of Hypoxia-inducible Factor-2 Alpha, is Regulated by von Hippel-Lindau Gene Mutation Status. Eur. Urol. 2016, 70, 623-632. [CrossRef] [PubMed]

86. Chen, J.; Jiang, C.C.; Jin, L.; Zhang, X.D. Regulation of PD-L1: A novel role of pro-survival signalling in cancer. Ann. Oncol. Off. J. Eur. Soc. Med. Oncol. 2016, 27, 409-416. [CrossRef] [PubMed]

87. Wang, Q.; Lin, W.; Tang, X.; Li, S.; Guo, L.; Lin, Y.; Kwok, H.F. The Roles of microRNAs in Regulating the Expression of PD-1/PD-L1 Immune Checkpoint. Int. J. Mol. Sci. 2017, 18, 2540. [CrossRef]

(C) 2019 by the authors. Licensee MDPI, Basel, Switzerland. This article is an open access article distributed under the terms and conditions of the Creative Commons Attribution (CC BY) license (http://creativecommons.org/licenses/by/4.0/). 